\title{
RISK ASSESSMENT IN RENEWABLE ENERGY PRODUCTION USING ANP
}

\author{
Sandija Rivza* \\ Latvia University of Agriculture \\ Jelgava, Latvia \\ E-mail: Sandija.Rivza@1lu.lv \\ Peteris Rivza \\ Latvia University of Agriculture \\ Jelgava, Latvia \\ E-mail: Peteris.Rivza@llu.lv
}

\begin{abstract}
Risk assessment is an important factor for successful entrepreneurship of bioenergy production that has become one of the priorities in energy sector of Latvia. Promotion of the use of renewable energy is included as one of the strategic goals for European Union (EU) and Latvia. As this field of energy production in Latvia is rather new and scantily explored there are many risk factors arising in different stages of production, starting with planning and building of a bioreactor and ending with production and further use and distribution of energy. The present research focuses on risk assessment in renewable energy production form biomass as this kind of energy is seen as a perspective source for renewable energy under the conditions of Latvia. A risk assessment module for renewable energy production made by using the Analytic Network Process (ANP) software is described in the paper.
\end{abstract}

Keywords: Analytic Network Process (ANP), renewable energy, risk assessment

\section{Introduction}

European Union (EU) consistently works on setting up a common energy policy with an important place allocated to the renewable energy production, energy efficiency, and energy security and independence. The new Directive on renewable energy (Directive 2009/28/EC of the European Parliament and of the Council) sets ambitious targets for all Member States: the share of energy from renewable sources in EU reaching $20 \%$ by the year 2020 (8.5\% in the year 2005), and a 10\% share of renewable energy specifically in the transport sector (EU Parliament, 2009). To reach this common goal, each member state has to increase the amount of renewable energy production and exploitation as a source for electricity, heating, cooling, and transportation. In the year 2010, renewable energy composed $37 \%$ in the total structure of energy in Latvia, with a target of reaching $40 \%$ in the year 2020. Currently, the most of the electricity from renewable resources is made from hydropower plants, but $1 \%$ of electricity in Latvia is produced by cogeneration of biomass, which is seen as a perspective source for increasing renewable energy production under the conditions of Latvia. To encourage the development of cogeneration plants, funding from the EU structural funds, Cohesion fund and European Agriculture Fond for Rural Development is available, and it is planned to attract 74 mill. lats (105 mill. euros) from the government of Latvia and the EU in the following years.

\section{Theories/Methods}

Even though the concept of risk dates back to the $18^{\text {th }}$ century, the awareness of risk and its role in the human society has become topical both theoretically and practically on the turn of the $21^{\text {st }}$ century and is linked with the ideas of two sociologists, Anthony Giddens and Ulrich Beck, who have admitted that modern society faces risk growth in comparison with the previous development stage (Giddens, 1999;

\footnotetext{
${ }^{*}$ Corresponding author
} 
Beck, 1992). The authors have introduced a new term risk society, describing modern society and its tight interaction with the various threats (Caplan, 2000). The quality of risk evaluation is combined of many factors. In terms of the origin of risk, depending on the aim of its classification, the subgroups of risk might be either all - embracing or very specific. For example, the international risk evaluation centre „RiskMetrics Group” suggests the range of 12 types including market, management, environment, social, accounting, legal, credit risks, etc. (RiskMetrics Group, 2008), jet some risk classifications include only two risk groups - external and manufactured risks (Giddens, 1999).

Although researchers of the Latvia University of Agriculture have a certain experience in working with risk determination and assessment issues in various fields of agriculture, veterinary medicine, food science, etc. (Risku faktoru..., 2004; Lauksaimniecības un pārtikas..., 2007; Riski lauksaimniecībā..., 2005), the field of renewable energy production is rather new and is scantily explored.

In this study, the Analytic Network Process (ANP) was used for risk assessment in renewable energy production as it allows including various factors and criteria - tangible and intangible (Saaty, 2010) - that is characteristic to risk assessment.

The ANP is a general theory of relative measurement used to derive composite priority ratio scales from individual ratio scales that represent relative measurements of the influence of elements that interact with respect to control criteria. Through its supermatrix whose elements are themselves matrices of column priorities, the ANP captures the outcome of dependence and feedback within and between clusters of elements. The Analytic Hierarchy Process (AHP) with its dependence assumptions on clusters and elements is a special case of the ANP. The ANP is a new and an essential phase in decision making, neglected so far because of the linear structures used in traditional approaches and their inability to deal with feedback in order to choose alternatives not simply according to attributes and criteria but also according to their consequences both positive and negative - an essential and so far a missing consideration in decision making (Saaty, 1999).

\section{Results and discussion}

In the present research risks are divided into 5 groups or clusters: personnel, production, property, environment, and legislative risks. They are evaluated by the ability to use one of three strategies - risk reduction, risk transfer, or risk undertaking strategy. The module allows detecting which is the dominant strategy in the whole risk assessment and which strategy is better for separate risks or risk groups. This module is designed to fit in the risk assessment system for agricultural enterprises made by the researchers of the Latvia University of Agriculture in the year 2009 following the Finnish module of risk assessment (Leppälä, 2008). The system generally is a questionnaire for farmers available online. Risk assessment is made from the answers of series of questions about the risk factors in the farm. There are 5 risk groups - the same as used in this particular research - production, property, environment, and legislative risks. Totally the system includes 772 questions, like „Is the noise level measured in the work place?” or „Is unauthorized access to premises averted?'. The choice of the farmer is made between 3 possible answers - „Yes”; „No"; „Partly”, and a possibility to indicate, that the question does not refer to the economic activities of the farm. Each of the questions has a coefficient determined by the experts, which is considered when summing the results. The results of the risk evaluation show the average risk levels in each section, lowest, highest and highly hazardous risks and the total risk level of all sections, additionally indicating the average risk level in Latvia. The mentioned system was suitable for various fields of agriculture (crop farming, dairy, livestock farming, etc.), but it did not include renewable energy production, therefore it is planned to combine these two systems (risk assessment by questionnaire and renewable risk assessment by ANP) in the future.

In the ANP module, each of the 5 groups includes several risks (Table 1). The group of personnel risks consisted of three risks that are connected with the responsibility, qualification and experience of employees and adherence of work safety on the production site. Production risks are the biggest group in our risk classification as it includes six risks that cover the bioenergy production process starting from the preparation of biomass and it`s quality to supply management, procession of biomass in the cogeneration 
process and the further use of electricity and heat. Property risks refer to the security and sustainability of the property that is used in the production. Environment risks mentioned in this assessment are closely linked with the procession phases of the energy production - storage and transportation of biomass, storage of digestate after the production of energy and use of the digestate in the fertilization of fields. The last group is legislative risks, these external risks are the ones that arise from the actions of governmental institutions - Ministry of Economics, Municipalities etc.

Table 1. Classification of accessed risks

\begin{tabular}{|c|c|}
\hline Risk group (cluster) & Risk \\
\hline 1.Personnel & $\begin{array}{l}\text { 1.1. Responsibility of the personnel } \\
\text { 1.2. Qualification and experience } \\
\text { 1.3. Work safety }\end{array}$ \\
\hline 2.Production & $\begin{array}{l}\text { 2.1.Quality of biomass } \\
\text { 2.2. Stability of the microbiological processes in } \\
\text { the bioreactor } \\
\text { 2.3. Regular supply of biomass } \\
\text { 2.4. Connection with the state electricity network } \\
\text { 2.5. Utilization possibilities of the produced heat } \\
\text { and their stability } \\
\text { 2.6. Accessibility of service for technical } \\
\text { equipment }\end{array}$ \\
\hline 3.Property & $\begin{array}{l}\text { 3.1. The outer security of the bioreactor and other } \\
\text { production facilities } \\
\text { 3.2. Credit risk } \\
\text { 3.3. Fire security }\end{array}$ \\
\hline 4.Environment & $\begin{array}{l}\text { 4.1. Storage of digestate } \\
\text { 4.2. Transportation of biomass } \\
\text { 4.3. Storage of biomass } \\
\text { 4.4. The use of digestate in the fertilization of fields }\end{array}$ \\
\hline 5.Legislative & $\begin{array}{l}\text { 5.1. Changes in energy policy } \\
\text { 5.2. Changes in the purchase tariffs }\end{array}$ \\
\hline
\end{tabular}

Besides five risk groups or clusters, the current risk assessment module includes 3 alternatives in the same level of risk groups: to reduce risks, to transfer risks, and to undertake risks. These alternatives illustrate the possible choices in risk management. The further analysis with the ANP method in the Superdecisions software is done to detect which alternative would be the best choice to each of the risks and risk groups (as an average value of all risks in the group). The Figure 1 shows the connections (influences) between risk groups and alternatives. The arrow from one cluster to another show that all or some elements in the first cluster influence all or some elements in the second cluster, but the reflexive loops (internal cycles) correspond to mutual influence between the elements in one cluster.

As it can be observed in the Figure 1, Production risks are the ones being the most influenced by all other risk groups - personnel risks (in the aspect of responsibility and qualification of workers and impact of these qualities to the biomass preparation, regular supply and management of the cogeneration processes), legislative risks (in terms of possibilities to connect to state electricity network, and utilize heat), Environment risks (as the need to follow the environment protection regulations in the production process) and property risk (in terms of production site fire-safety and outer security, recoupment/credit risk, also affected by purchase tariffs). All risk groups and alternatives have the inner dependence - one of the elements in the cluster influences other elements in the same cluster, for example the risk, ,changes in the energy policy" in the cluster "legislative risks" influence the risk ,changes in the purchase 
tariffs", because the purchase tariffs are set by the government and therefore influenced by political decisions.

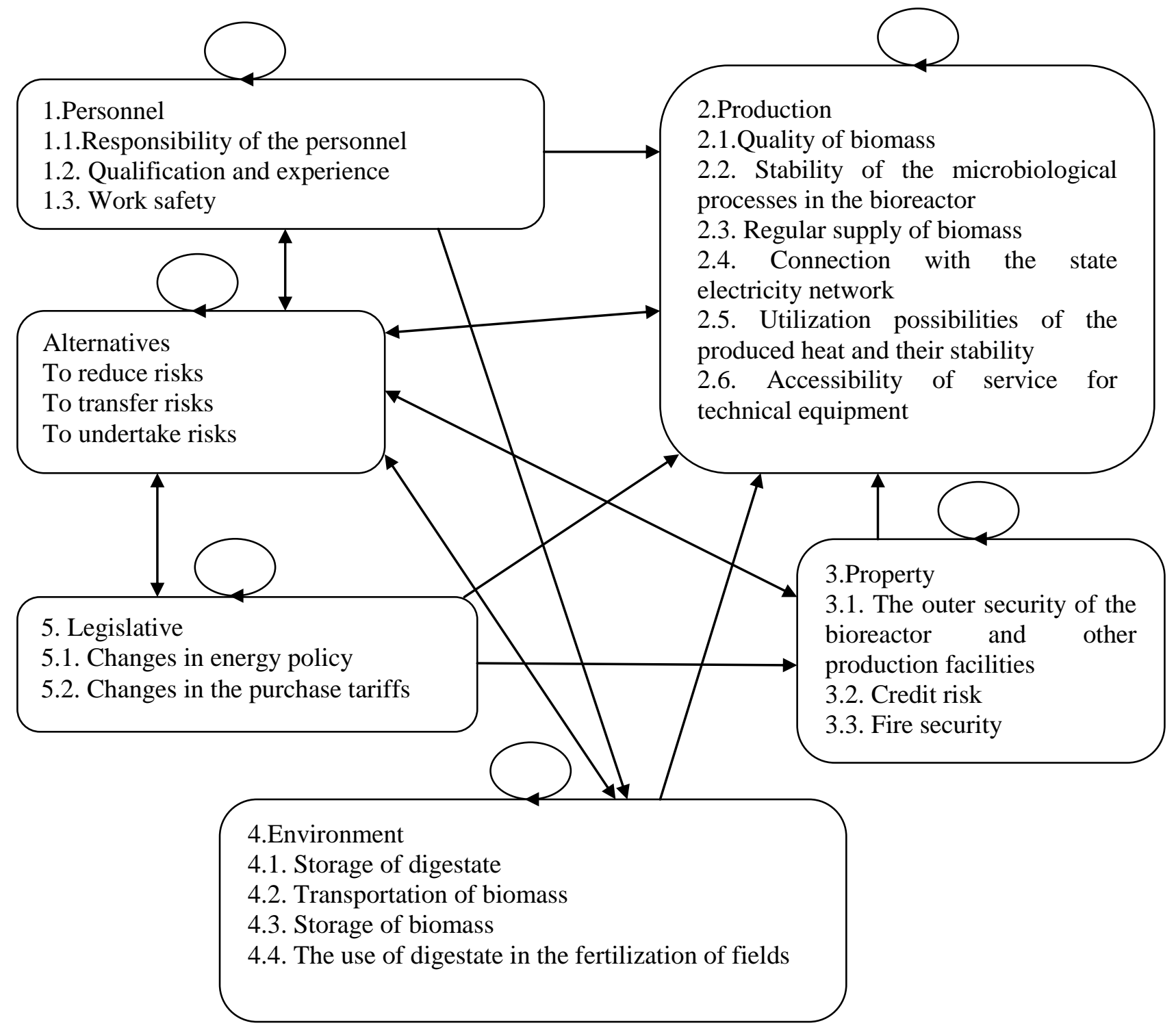

Figure 1. The influence graph describing relations between risk groups

After the determination of influences clusters and nodes of related risks were evaluated. In ANP an intensity of influence is being estimated by the experts with use of pairwise comparison's procedure and the fundamental ratio scale (Saaty T.L., 2001). Pair comparison technique is the most universal method of measurements, as it can be applied at absence of any scales and standards, in particular at a measurement of intangible attributes. Comparing two objects with respect to a common attribute (criterion, property) the expert estimates a relative preference of one object over another, choosing a suitable estimation from the fundamental scale (Andreichicova, 2007). In this case the importance or significance of one element over another element is measured.

The results of the performed assessment show (Figure 2) that the alternative that is rated as the best choice for risk management is to reduce risks (average value of all risk groups is 0.21 ), although the 
transfer of risk shows a high dispersion (average: 0.176; min: 0.023; max: 0.522) displaying that this alternative is highly suggested for certain risks or risk groups and avoidable or impossible for other.

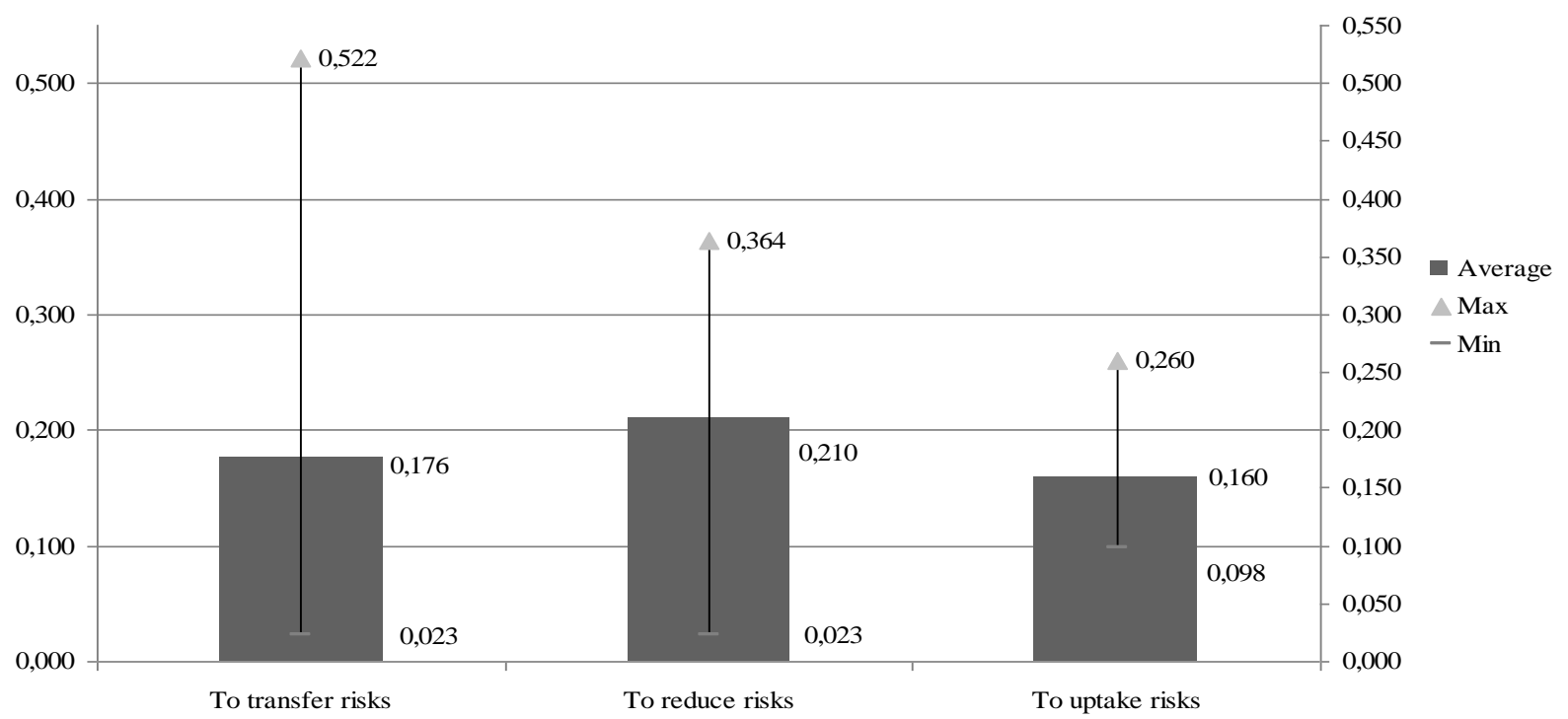

Figure 2. Assessment of alternatives

The Figure 3 alowes to identify the sutability of alternatives to risk groups. As it can be seen, legislative risks, according to the assesment (0.209), are not highly managable in terms of transfer or reduction, one can uptake these risks and pay attention to changes, for example, follow up the drafting process of new government regulations that includes tarif change, but there are minor possibilities of affecting these processes from the energy producers point of view. Also in the production risks group there is a high evaluation for the alternative of uptaiking risks (2.6), meaning, that not all problems in production process can be forecasted and reduced, jet ,to reduce risks" is the highest evaluated alternative (3.18) in this group, showing the high need of control in the production procesess. Personell and Environment risks are adviced to be reduced ( 0.218 and 3.64 respectively), but the property risks in this research are suggested to be transferred (0.522), for example with ensurance, jet some of these risks could be reduced or uptaken. 


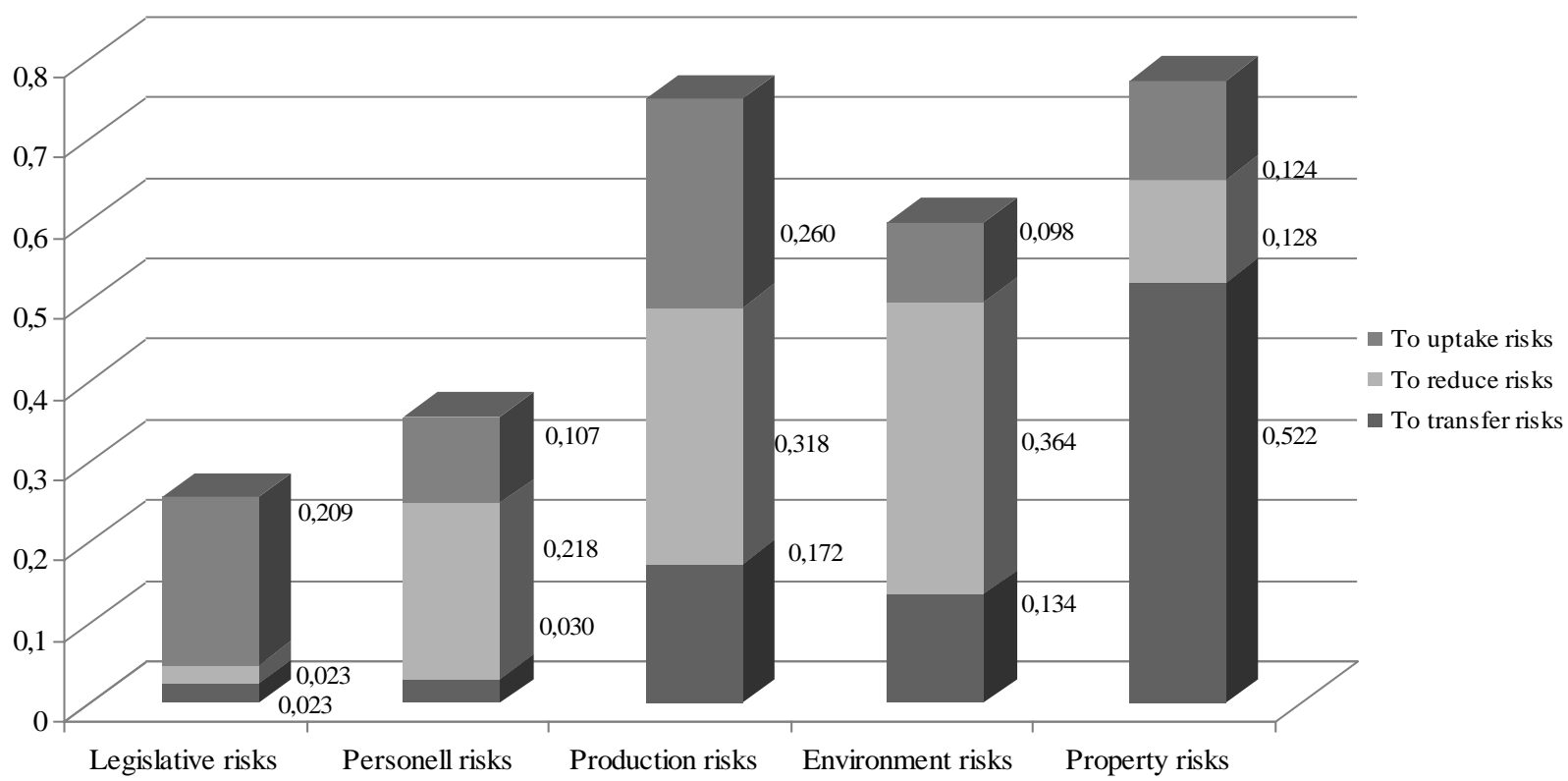

Figure 3. Choice of alternatives within the risk groups

\section{Conclusions}

The use of ANP in risk management gives an opportunity to perform the risk assessment by including tangible and intangible factors, and to evaluate various dependencies between risks and alternatives, making it a valuable tool for risk assessment.

The current risk assessment in renewable energy production shows that most of the risks are suggested to be reduced (personell, production and environment risks) or transferred (property risks in particular), jet there are several risks, mainly in the group of legislative risks, that can be only uptaken id est taken into further consideration.

\section{Acknowledgements}

This publication has been prepared within the framework of the ESF Project „Attraction of human resources to the research of the renewable energy sources", Contract Nr. 2009/0225/1DP/1.1.1.2.0/09/APIA/VIAA/ 129.

\section{References}

Andreichicova O.N. , Radyshevskaya T.N. (2007) Application of the Analytic Network Process to a forecasting of oral health, Proceedings of the ISAHP, Vina Del Mar, Chile, August 3-8, 2007

Beck, U. (1992) Risk Society:Towards a New Modernity. New Delhi: Sage.

Caplan, P. (2000) Risk Revisited, Pluto Press, London, P. 7.

Directive 2009/28/EC of the European Parliament and of the Council of 23 April 2009 on the promotion of the use of energy from renewable sources (2009) European Parliament [Online] Available at: http://eurlex.europa.eu/LexUriServ/LexUriServ.do?uri=CELEX:32009L0028:EN:NOT

Giddens, A. (1999) Risk and Responsibility. Modern Law Review 62(1); pp.1-10. 
Latvijas politika atjaunojamo energoresursu jomā (2010) Ministry of Economics of the Republic of Latvia [Online] Available at: http://old.em.gov.lv/em/2nd/?cat=14281

Lauksaimniecības un pārtikas risku vadī̌̆ana (2007). Red. Rivža P. Jelgava, LLU: pp. 41.-51.

Leppälä, J., Murtonen, M., Suutarinen, J. (2008) Farm-RM - risk management tools for farms

Proceedings of the Nordic Association of Agricultural Scientists asociation seminar No 410, NJF Report Vol 4, No 7 , pp. 22.-25.

Riski lauksaimniecībā un privātajā mežsaimniecībā (2005). Red. Rivža P. Jelgava, LLU: Monograph, pp. 47.-59.

RiskMetrics Group (2010) [Online] Available at: http://www.riskmetrics.com

Rivža, P. (2004) Riska faktoru izvērtēšana un riska vadība Latvijas lauksaimniecībā. Latvijas Lauksaimniecības universitātes Raksti, LLU, Nr. 11, pp. 3.-8.

Saaty T.L. (2001), Decision making with dependence and feedback. The analytic network process, Pittsburgh: RWS Publications.

Saaty Thomas L. (1999) Fundamentals of the Analytic Network Process, Proceedings of the ISAHP, Kobe, Japan, August 12-14, 1999

Saaty, Thomas L. (2010) Principia Mathematica Decernendi: Mathematical Principles of Decision Making, RWS Publications, Pittsburgh, PA, USA. 